\title{
Peningkatan Motivasi Berwirausaha dan Mutu Usaha Mikro Melalui Pelatihan Berbasis Konsep Magnet Rejeki
}

\author{
Arif Julianto Sri Nugroho, Anis Marjukah, M Pujo Darmo, Dandang Setyawanti, \\ Agung Nugroho Jati, Cahaya Nugrahani, Jarot Prasetyo \\ Universitas Widya Dharma Klaten, Klaten, Indonesia \\ arifjuliantosn72@gmail.com
}

Received: $9^{\text {th }}$ September 2020 | Accepted: $19^{\text {th }}$ July $2021 \mid$ Published: $27^{\text {th }}$ July 2021

Key word:

Busines

motivation;

magnet rejeki;

training;

performance

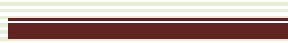

Kata Kunci

Motivasi bisnis; magnet rejeki; pelatihan; kinerja

\section{Abstract}

Self-business micro which can live, survive through generation, and reach the dream is the expectation from the owner. There are many factors which can determine the success of the businessman to fight from the competition. One factor is the ability to respond the internal and external changes rapidly and exactly. The ability to win the competition, the ability to read the situation, the ability to collaborate with other to have a synergy, and the ability to adapt from the competition are the keys toward the business sustainability. This community service aims to test the model of business training based on the concept of 'magnet rejeki' which can give a significant influence toward the motivation of micro business. The method of the study is development model by entrepreneurship training that are integrated input by including the businessman on factors which influence their motivation in the beginning of their business, the business motivation training based on the concept of 'magnet rejeki', and visit business collaboration and monitoring. The result of this study give the conclusion that the business training based on the concept of 'magnet rejeki' is effective to conduct by the proof that there is an increase of motivation to have a business and business profit after the training.

\section{Abstrak}

Wirausaha mikro mandiri yang mampu hidup dan bertahan selama beberapa generasi serta mampu mencapai mimpi yang dicita-citakan merupakan harapan setiap pendirinya. Ada banyak faktor yang menentukan keberhasilan wirausaha untuk bertahan dari kerasnya kompetisi. Faktor itu antara lain kemampuan merespon perubahan internal dan eksternal dengan cepat dan tepat. Kemampuan memenangkan persaingan, dapat membaca situasi, berkolaborasi dengan pihak lain untuk bersinergi serta kemampuan beradaptasi dalam persaingan merupakan kunci terhadap keberlanjutan usaha. Kegiatan ini bertujuan menguji kegiatan pelatihan wirausaha berbasis konsep magnet rejeki memiliki pengaruh positif dan signifikan terhadap motivasi berwirausaha. Kegiatan dilakukan berupa pelatihan wirausaha. Operasionalisasi kegiatan meliputi integrasi input melibatkan pelaku usaha mikro rintisan awal, proses berupa pelatihan motivasi wirausaha berbasis magnet rejeki, pelatihan manajemen produksi, keuangan, pemasaran, visit bisnis, pendampingan serta monitoring. Hasil kegiatan memberikan simpulan kegiatan pelatihan wirausaha berbasis magnet rejeki efektif dengan bukti semakin meningkatnya motivasi wirausaha serta meningkatnya omset usaha setelah kegiatan pelatihan. 


\section{PENDAHULUAN}

Usaha mikro nasional saat ini dengan adanya pandemi Covid-19 benarbenar mendapatkan ujian berat. Para pelaku di sektor makanan dan minuman yang biasanya mengandalkan kerumunan pengunjung sekarang mengalami kemerosotan omset dengan berubahnya pola kegiatan masyarakat untuk menghindari kerumunan. Mereka saat ini mulai melakukan pembelian secara take away, delivery maupun model interaksi menggunakan aplikasi daring.

Usaha mikro adalah tulang punggung perekonomian nasional. Bersama UKM kontribusinya terhadap produk domestik bruto nasional sekitar 60 persen dan menyerap 97 persen tenaga kerja nasional. Omset usaha mikro per hari menurut data Kementrian Koperasi UMKM pada tahun 2020 sekitar Rp 230.000. Jika diambil marjin sekitar 20 persen, penghasilan mereka hanya $\mathrm{Rp}$ 42.000 per hari. Sedangkan jumlah pelaku usaha mikro sekitar 62 juta, merupakan 98 persen dari semua pelaku usaha nasional (Budimanta, 2020)

Dalam situasi pandemi, SMRC (2020) meneliti bahwa kondisi ekonomi memburuk di tingkat rumah tangga dirasakan oleh 79 persen responden dan tingkat nasional oleh 84 persen warga seluruh tanah air. Atas dasar itu, semakin lama pandemi berlangsung, semakin banyak pelaku usaha mikro menutup usaha dan merumahkan pekerja akan semakin menambah jumlah kemiskinan. Lembaga riset Smeru (2020) memperkirakan penambahan jumlah orang miskin menjadi 1.3 juta sd 8.45 juta orang akibat Covid-19 serta pertumbuhan ekonomi Indonesia diperkirakan akan menurun ke kisaran minus 4.2 persen hingga minus 1 persen di tahun 2020.

Dari kondisi pandemi saat ini, konsumen muslim di Indonesia akan semakin mencari manfaat fungsional barang dan jasa sesuai konsep halalan dan thoyyiban karena semakin menurunnya daya beli, mereka juga mulai mencari barang dan jasa yang memiliki manfaat emosional. Saat ini masyarakat muslim semakin peduli dan butuh untuk mendapatkan manfaat spiritual (spiritual value) dari suatu komoditas yang mereka pakai. Manfaat spiritual adalah manfaat yang terkait seberapa jauh produk, jasa serta upaya memproduksi barang dan jasa melalui kegiatan wirausaha mematuhi nilai-nilai dari ajaran Islam. Upaya untuk selalu mematuhi ajaran Islam adalah salah satu bagian yang dipelajari dalam konsep magnet rejeki (Nasrullah, 2019).

Upaya meredam dampak Covid-19 akan lebih efektif jika dilakukan melalui upaya meningkatkan daya tahan pelaku 
usaha mikro. Dengan menyelamatkan 'usaha rakyat' ini, Pemerintah mendapatkan dua keuntungan sekaligus yaitu pertumbuhan ekonomi tidak terjun bebas serta pengangguran dan kemiskinan tidak akan bertambah. Salah satu upaya mempertahankan daya tahan pelaku usaha mikro adalah terus memompa semangat motivasi, etos wirausaha muslim melalui kegiatan pelatihan manajemen wirausaha terstruktur.

Dari analisis situasi di atas, ada beberapa masalah khusus yang dihadapi oleh mitra pelaku usaha mikro muslim di Kabupaten Klaten untuk mengembangkan usaha. Aspek itu antara lain aspek motivasi berwirausaha, aspek modal, produksi, pemasaran dan aspek manajemen usaha. Masalah pertama yaitu motivasi wirausaha yang mudah menyerah. Merebaknya pandemi Covid-19 di wilayah Klaten dipastikan mempengaruhi kontinuitas dan volume usaha, masalah kedua, modal yang digunakan masih dominan modal pribadi, memiliki sifat terbatas dan tidak terlalu besar. Dengan modal terbatas untuk mengembangkan usaha dibutuhkan tambahan bantuan modal. Masalah ketiga, masalah proses produksi mencakup: macam/jenis variasi olahan bahan baku, penyajian, variasi olahan produk sisa bahan baku dan kualitas produk yang masih perlu ditingkatkan.
Mutu produk yang dihasikan mitra perlu terus untuk ditingkatkan agar mereka memiliki kemmampuan bersaing. Masalah keempat pemasaran, perlu ditata dan ditingkatkan model serta cara memasarkan barang secara modern di era pandemi Covid-19 pada saat ini sehingga diharapkan jaringan pemasaran mitra menjadi semakin luas.

Melihat beberapa permasalahan yang dihadapi mitra maka perlu prioritas terhadap solusi masalah melalui kegiatan ini. Setelah melalui pertimbangan kemampuan tim pengabdi, permasalahan yang diprioritaskan untuk diatasi melalui pelatihan adalah:

1. masalah motivasi berwirausaha

2. masalah manajemen keuangan

3. masalah peningkatan mutu proses produksi

4. masalah manajemen pemasaran.

Selain kegiatan pelatihan berbasis motivasi, kegiatan ini juga merupakan luaran wajib penelitian unggulan Universitas Widya Dharma melalui pelatihan wirausaha terstruktur. Kegiatan ini bisa bermanfaat secara nyata bagi meningkatnya motivasi wirausaha pelaku usaha mikro muslim di Kabupaten Klaten.

Dari latar belakang sebagai acuan ditarik rumusan masalah kegiatan: "Bagaimana faktor-faktor pemicu motivasi dalam konsep magnet rejeki melalui 
kegiatan pelatihan bisa memengaruhi meningkatnya motivasi berwirausaha, meningkatnya kemampuan tata kelola keuangan, ketrampilan manajemen produksi dan meningkatnya kemampuan pemasaran modern era pandemi Covid-19 pelaku usaha mikro muslim di wilayah kabupaten Klaten “.

Kegiatan ini bertujuan untuk menguji model pelatihan terstruktur berbasis konsep magnet rejeki bisa berperan untuk mencapai keunggulan bersaing pelaku wirausaha yang bermuara meningkatnya mutu usaha dan pertumbuhan ekonomi. Dengan diketahui manfaat nyata pelatihan, terbuka peluang menangkap pasar konsumen muslim sehingga kinerja usaha mikro semakin meningkat. Munculnya berbagai pelaku wirausaha mikro muslim yang berdaya saing memiliki manfaat posiitf bagi tumbuhnya ekonomi syariah dan semakin sejahtera masyarakat.

\section{METODE}

Program pengabdian kepada ini menggunakan metode sebagai berikut:

1. Kerangka Kegiatan pelatihan dijabarkan pada gambar 1

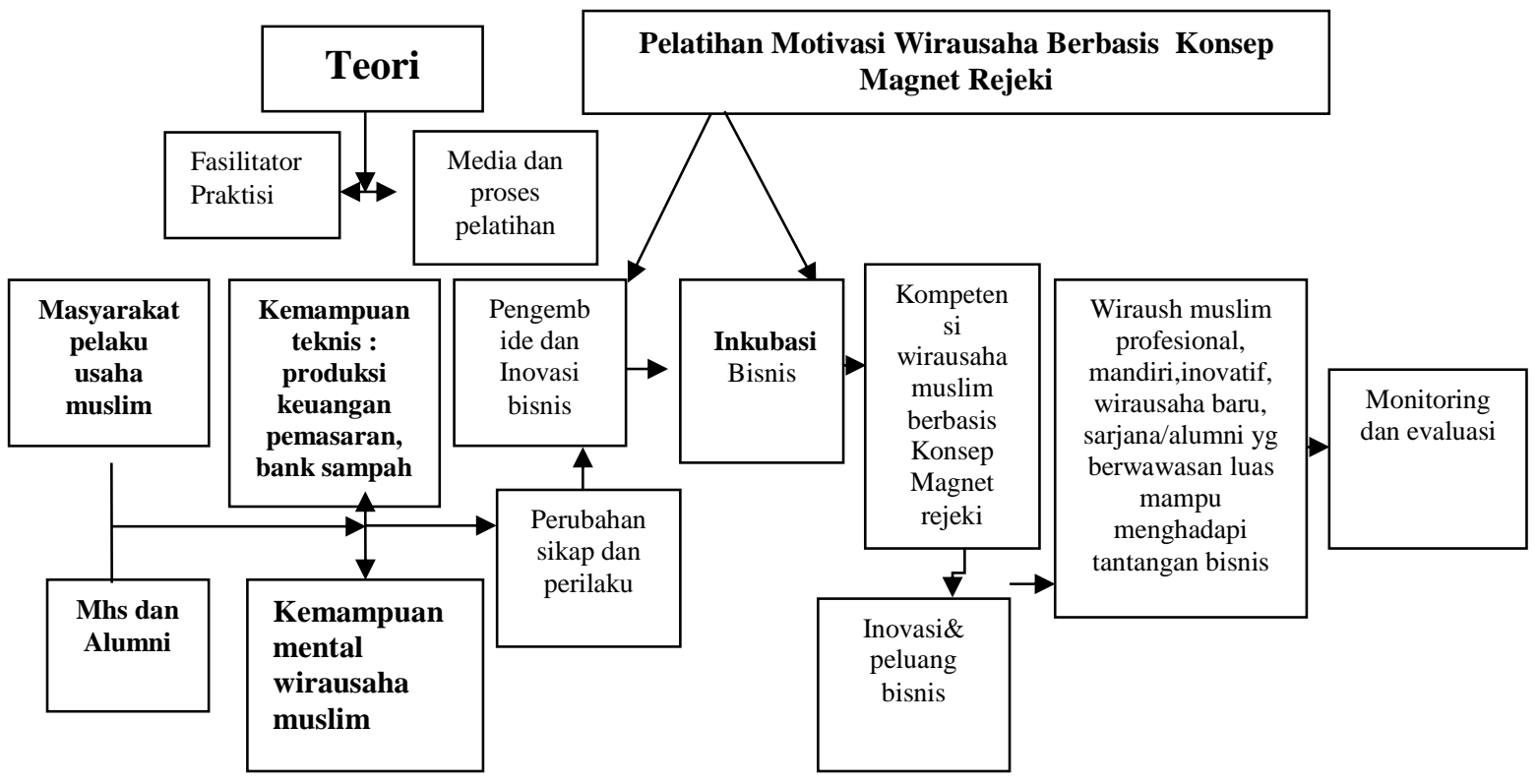

Gambar 1. Kerangka kegiatan pelatihan magnet rejeki

2. Operasionalisasi Kegiatan

Operasionalisasi kegiatan diurai sebagai berikut:

a. Input, dalam kegiatan ini input berupa wirusaha pemula, wirausaha muslim mikro yang baru eksis serta mahasiswa dan alumni yang memiliki motivasi kuat berwirausaha, memiliki modal baik 
berupa modal materi maupun nonmateri

b. Proses Pelatihan motivasi wirausaha Berbasis Magnet

Rejeki. Kegiatan dilakukan melalui pelatihan sebagai upaya memompa motivasi wirausaha peserta antara lain kemampuan mental dan sikap dalam konsep magnet rejeki: : ghiroh, taat beribadah, menjauhi maksiat, berfikir dan bertindak positif, syukur dan penguasaan fikiran.

\section{c. Proses Pelatihan kemampuan} teknis. Dalam kegiatan tahap lanjut dilakukan pelatihan kemampuan teknis: analisis kelayakan bisnis: pemasaran keuangan dan produksi, pengenalan tugas, alat dalam kegiatan wirausaha sosial bank sampah, pemeliharaan dan kesehatan kerja dalam kondisi melakukan usaha sesuai protokol kesehatan pandemi Covid-19, problem solving bisnis, visit bisnis dan kegiatan pembentukan team building

d. Output, dari kegiatan diharapkan muncul inkubasi bisnis, adanya perubahan sikap dan perilaku sebelum dan sesudah kegiatan pelatihan e. Outcome, tercipta inovasi peluang bisnis wirausaha muslim yang telah eksis maupun baru. Mereka menjadi wirausaha muslim yang profesional, inovatif serta mahasiswa-alumni yang berwawasan mandiri

f. Monitoring, evaluasi kegiatan dilakukan setelah materi pelatihan diberikan kepada peserta. Evaluasi tidak hanya dilakukan serta merta selepas kegiatan berlangsung tetapi terus ada pemantauan bagaimana kondisi model bisnis peserta setelah kegiatan. Evaluasi menyeluruh dilakukan untuk mengetahui sejauh mana tingkat keberhasilan program di masa mendatang bisa diterapkan oleh mitra pelaku usaha serta untuk lebih meningkatkan kualitas program

g. Lokasi kegiatan, pelatihan motivasi Wirausaha Berbasis Magnet Rejeki dilakukan di beberapa lokasi di wilayah Kabupaten Klaten meliputi Hotel Bima dan kampus Universitas Widya Dharma. Lokasi lain praktek pelatihan pelaku usaha mikro makanan di Kota Klaten serta praktek pelatihan wirausaha bank sampah di wilayah Kabupaten Sukoharjo 


\section{Pelatihan Motivasi Wirausaha berbasis} Konsep Magnet Rejeki.

Kegiatan dilakukan secara terstruktur berupa pemberian kuliah klasikal, tanya jawab, pemberian tugas-tugas, case study serta bermain peran ( role playing). Kegiatan pelatihan dilaksanakan selama dua hari penuh berupa pelatihan knowledge bisnis, pembekalan motivasi dan etos kewirausahaan muslim berbasis konsep magnet rejeki, problem solving, pengetahuan akses pasar, analisis modal kerja, produk dan pemasaran, kelayakan bisnis, pembentukan bisnis model serta solusi pemecahan masalah.

Pelatihan wirausaha yang diberikan selama dua hari memiliki materi yang dibagi dalam empat sesi yaitu: a) sesi inspirasi sukses wirausaha muslim basis konsep Magnet Rejeki b) sesi potensi diri yang luar biasa serta upaya melejitkan motivasi dan potensi wirausaha muslim, c) sesi sejuta berkah dalam bekerja, dimana peserta mampu mensyukuri limpahan berkah yang luar biasa besar dari Alloh SWT dalam bekerja. Dari sesi ini diperoleh energi awal yang memadai dalam memulai dan melanjutkan aktivitas wirausaha d) sesi kempuan teknis aspek manajemen usaha meliputi aspek keuangan, produksi dan pemasaran usaha mikro.

Materi kunci Magnet Rejeki yang diajarkan meliputi tiga hal yaitu Positive
Thinking artinya setiap pikiran adalah doa, law of projection, Positive Feeling meliputi ilmu paradox of candy, duduk di taman dan Ilmu garpu Tala serta Positive Motivation meliputi ilmu the Power of Mother ( Nasrullah, 2019)

Aspek Pemasaran modern yang diajarkan meliputi konsep lingkungan bisnis, segmentasi pasar, targeting, posisioning serta strategi pemasaran modern daring di era Covid-19. Dasar dari ilmu pemasaran adalah segala upaya, kegiatan usaha untuk memuaskan konsumen

Aspek keuangan yang diberikan berupa pelatihan kepada kepada mitra meliputi dasar-dasar ilmu manajemen keuangan, dasar- dasar akuntansi, konsep neraca dan laporan R/L. Peserta diharapkan mampu menyusun cash flow atau aliran kas yang memuat investasi atau capital outlays serta proceed atau cash inflow. Kegiatan ini akan bermuara kepada meningkatnya mitra menyusun studi kelayakan bisnis untuk diajukan tambahan modal usaha/ pembiayaan pada bank mitra yaitu Bank Jateng Syariah Kabupaten Klaten. Meningkatnya kemampuan mitra dalam membuat analisis investasi usaha seperti kemampuan analisis Average Accounting Rate of Return, Payback Period, Net Present Value, Internal Rate of Return dan Benefit Cost Ratio akan 
menarik bank mitra untuk menambah modal usaha karena usaha dinilai feasibel. Dokumentasi kegiatan pelatihan disajikan dalam gambar 2 berikut:

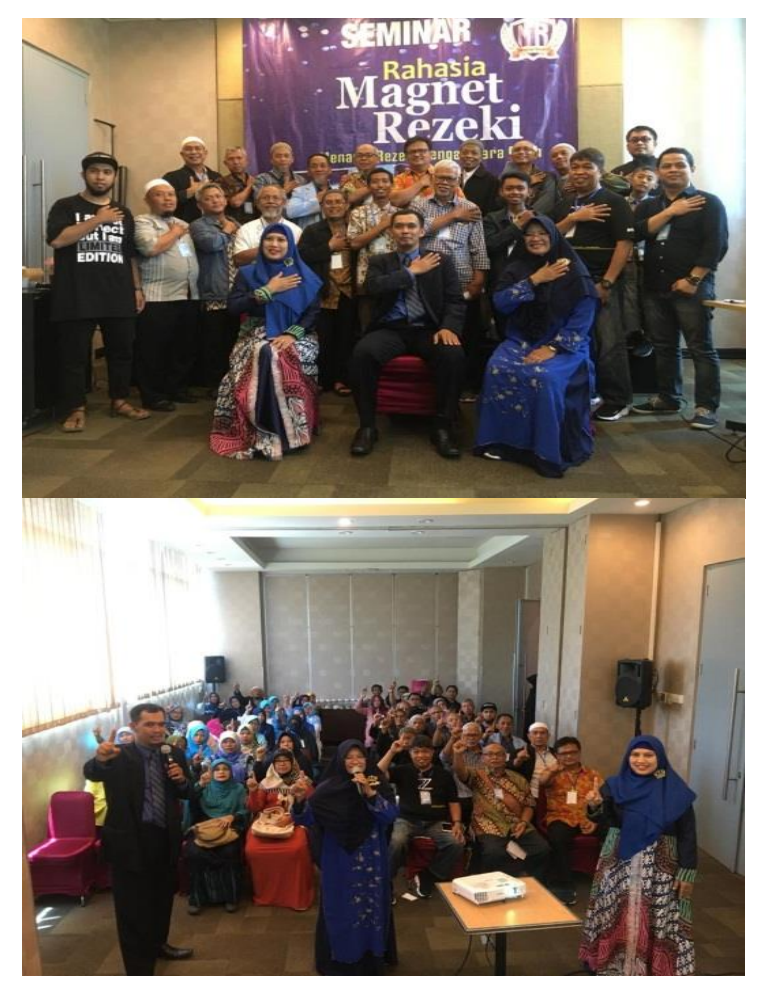

Gambar 2. Pelatihan motivasi wirausaha berbasis konsep Magnet Rejeki

\section{Pelatihan Proses Produksi Usaha}

\section{Makanan}

Keahlian yang diperlukan dalam kegiatan ini adalah bidang rekayasa teknologi tepat guna, proses olah produk melalui alih daya kemampuan anggota mentor yang memiliki keahlian membuat olahan nasi bakar. Mentor dan praktisi wirausaha ini telah eksis memiliki jaringan usaha di beberapa tempat di kota Klaten. Dalam kegiatan dipelajari analisis kekuatan kelemahan peluang dan ancaman usaha (SWOT), pelatihan proses produksi dan inovasi ragam produk, analis perputaran modal, target pasar yang akan dibidik, sistem penjualan, analisis sistem bisnis, solusi meminimalkan risiko serta nilai-nilai etos wirausaha muslim yang diyakini

Pelaku wirausaha memberikan sharing pengalaman usaha kepada peserta pelatihan. Etos wirausaha muslim seperti kerja keras, rasa syukur, qonaah, menghindari diri takabur, riya'l pamer sangat relevan dilakukan dalam kegiatan usaha. Pelaku memaparkan salah satu pengalaman diri apabila muncul rasa takabur, kejadian diluar dugaan semisal proses menanak nasi yang bisa lama atau bahkan nasi tidak matang padahal kegiatan sudah dilakukan sesuai proses standar bisa terjadi. Oleh karena itu penting sekali penanaman etos wirausaha Muslim seperti yang dicontohkan Rasulullah SAW kepada peserta pelatihan. Dokumentasi kegiatan pelatihan proses produksi olah bahan makanan disajikan dalam gambar 3 berikut:

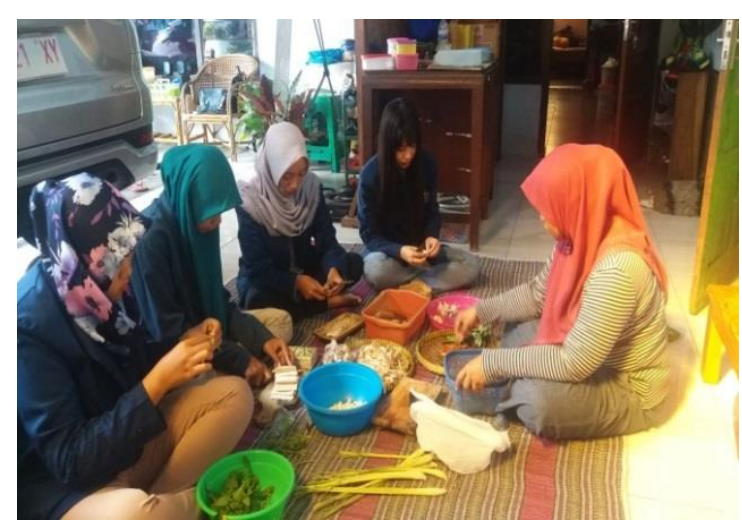




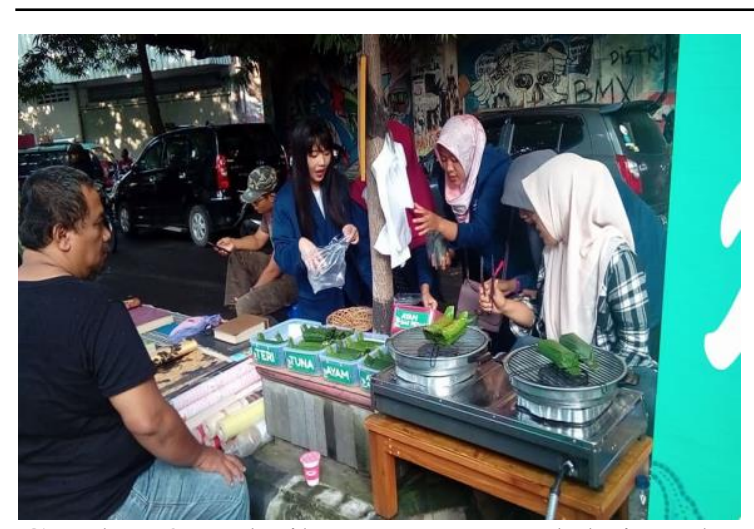

Gambar 3. Pelatihan proses produksi usaha makanan

\section{Pelatihan Wirausaha Sosial Bank Sampah}

Selalu mencintai lingkungan dengan tidak membuat kerusakan di muka bumi merupakan wujud nyata penerapan konsep Magnet Rejeki. Peserta pelatihan dilatih di lapangan dengan mempelajari praktek wirausaha sosial bank sampah dari output peserta hasil pelatihan tahap sebelumnya. Mekanisme kerja bank sampah yang dipelajari meliputi: pemilahan sampah, penyetoran, penimbangan, pencatatan dan pengangkutan. Sampah dibedakan sampah organik dan non-organik. Sampah organik didaur ulang dengan dikomposkan sehingga terurai ke alam. Sampah non organik meliputi sampah gelas/ kaca, kaleng/ metal, kertas dan plastik.

Pada kegiatan ini dipelajari tolak ukur keberhasilan dan ketidakberhasilan semisal reduksi sampah dan omset. Dilakukan kuantifikasi indikator berupa meningkatnya kebersihan lingkungan, meningkatnya kesehatan masyarakat serta meningkatnya penghasilan tambahan. Dokumentasi kegiatan pelatihan wirausaha bank sampah peserta disajikan dalam gambar 4 berikut

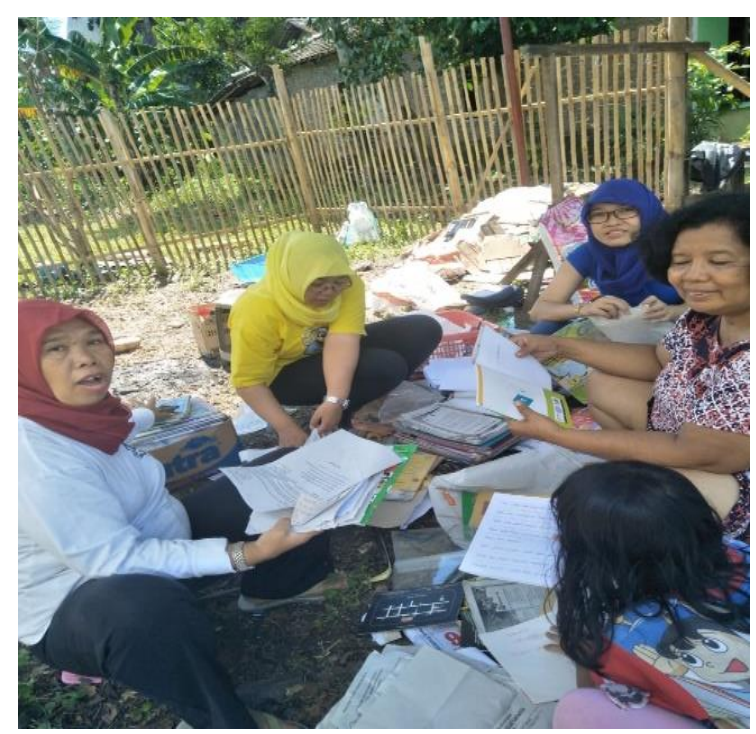

Gambar 4. Praktek bank sampah

\section{PEMBAHASAN}

Evaluasi untuk mengetahui Efektivitas

\section{Pelatihan}

Berdasarkan evaluasi disimpulkan bahwa model pelatihan motivasi wirausaha berbasis konsep Magnet Rezeki melalui kegiatan pelatihan, praktek bisnis, serta visit bisnis efektif. Mutu dan luaran kegiatan dilakukan melalui uji kuantitatif eksperimen untuk menilai motivasi wirausaha melalui pembelajaran secara klasikal, motivasi sebelum pelatihan dan sesudah kegiatan. Efektivitas pembelajaran diperoleh dari hasil umpan balik uji kuantitatif kuesioner ada kepuasan peserta terhadap mutu pelatihan. Dari nilai uji 
didapat nilai beda sebelum dan sesudah kegiatan.

Uji kuantitatif regresi diperoleh persamaan positif berarti apabila ada kenaikan satu satuan kegiatan pelatihan akan meningkatkan motivasi wirausaha sebesar 0.65 satuan. Nilai uji korelasi diperoleh sebesar 0.852 artinya kegiatan memiliki pengaruh sangat kuat. Dari uji t diperoleh probabilitas 0.000 berarti Hipotesis nol ditolak. Artinya kegiatan pelatihan motivasi wirausaha berbasis Magnet Rezeki memiliki pengaruh positif dan signifikan dalam menumbuhkan minat wirausaha. Hasil uji koefisien determinasi sebesar 0.725 artinya kegiatan pelatihan motivasi wirausaha berbasis Magnet Rezeki memiliki pengaruh $72 \%$ terhadap meningkatnya minat wirausaha, sedangkan $28 \%$ dipengaruhi faktor lain yang belum diteliti dalam kegiatan pelatihan.

Implementasi kecerdasan spiritual Islam yang mampu menggerakkan sikap manusia lewat dukungan suara hati bertransformasi dengan akal manusia memacu motivasi wirausaha untuk menggapai sukses. Nilai-nilai yang terkandung tersebut bertransformasi dengan akal manusia. Nilai-nilai yang terkandung di dalam kecerdasan spiritual Islam ini memberikan makna mendalam sehingga terefleksi melalui ucapan, sikap hingga pemikiran yang berakhlak mulia.
Kegiatan ini populer dengan istilah Ihsan, yaitu bekerja serasa melihat Allah SWT dan bekerja atas nama Allah SWT sehingga berpotensi bagi tercapainya keberlangsungan usaha yang sesuai dengan norma syariat Islam (Hijriah, 2016)

Pelatihan wirausaha berbasis spiritualitas telah dilakukan peneliti dan pengabdi lain seperti Yuwono (2008). Dari riset diperoleh temuan hasil kegiatan efektif. Masalah yang ditemui dalam observasi kegiatan wirausaha bank sampah adalah kurang trampilnya sumber daya manusia pengelola, keengganan sebagian masyarakat untuk mengumpulkan sampah akibat kondisi work from home di era pandemi Covid-19 sehingga mobilitas masyarakat berkurang. Kondisi persaingan juga muncul antar bisnis yang sama dimana pesaing bisa menerima barang dengan harga beli yang lebih tinggi. Kondisi ini merupakan pembelajaran bagi peserta pelatihan motivasi wirausaha. Temuan ini juga sesuai hasil riset Wulandari et.al (2017) sehingga perlu adanya evaluasi terkait tindak lanjut penyempurnaan mutu materi pelatihan pembelajaran wirausaha social.

\section{SIMPULAN}

Dari pembahasan yang diperoleh ditarik beberapa simpulan antara lain: 
1. Kegiatan pelatihan motivasi wirausaha berbasis konsep Magnet Rezeki berorientasi inovasi merupakan model pelatihan yang berkelanjutan, dalam arti peserta tidak hanya dibekali kegiatan pelatihan motivasi tetapi diwajibkan melakukan praktik wirausaha. Sehingga diperoleh output kegiatan pelatihan yang handal dan mandiri

2. Kegiatan pelatihan berpengaruh positif terhadap meningkatnya pengetahuan, sikap perilaku dan ketrampilan serta sangat mendukung kompetensi wirausaha peserta

3. Kegiatan pelatihan mampu menggali, mengoptimalkan dan menyalurkan potensi bakat serta minat peserta. Hal ini ditemukan saat dilakukan monitoring bisnis peserta pasca pelatihan

4. Kegiatan pelatihan memiliki dampak yang baik bagi peserta sehingga mereka berminat untuk menyebarluaskan pengetahuan wirausaha yang telah dimiliki kepada orang lain, memiliki motivasi, tanggung jawab, kreatifitas, inovasi dan percaya diri yang tinggi serta meningkatnya omset usaha peserta

5. Kegiatan pelatihan motivasi wirausaha berbasis konsep Magnet rezeki yang dikembangkan pada kelompok eksperimen dinyatakan efektif. Efektivitas kegiatan dapat dilihat dari tercapainya tujuan, ouput dan outcome pelatihan sesuai prioritas dan tujuan yang ditetapkan. Kegiatan ini memiliki kesesuaian dengan kebutuhan belajar, memiliki pengaruh positif terhadap meningkatnya pengetahuan, sikap, perilaku, ketrampilan dan mendukung peningkatan kompetensi wirausaha muslim.

\section{SARAN}

Beberapa hal yang perlu disarankan berdasarkan hasil yang diperoleh dari pelatihan magnet rejeki adalah:

1. Perlu diteliti lebih lanjut kegiatan pelatihan motivasi wirausaha basis Konsep Magnet Rezeki dengan pendekatan multi disiplin, multi model dan multi paradigma sehingga dapat menyumbang lebih beragam khasanah keilmuan wirausaha yang lebih kokoh.

2. Materi praktik bisnis terapan proses produksi dan pembelajaran model pemasaran modern dalam kondisi pasca Covid-19 di masa mendatang perlu diperbanyak bagi peserta

\section{UCAPAN TERIMA KASIH}

Ucapan terima kasih kepada Kepala Puslit dan Kepala PPM Universitas Widya Dharma atas fasilitasi skim Penelitian 
Unggulan dan Abdimas program studi tahun 2020

\section{DAFTAR PUSTAKA}

Budimanta, A. (2020). Usaha Mikro di Tengah Pandemi. Opini. Kompas: Harian Nasional, 18 Juni 2020

Hijriah, Y.H. (2016). Spiritualitas Islam Dalam Kewirausahaan. Jurnal Tsaqafah: Jurnal Peradaban Islam, 12 (1), 187-208

Nasrullah. (2016) Rahasia Magnet Rezeki: Menarik Rezeki Dahsyat Dengan Cara Allah, (Edisi.16). Jakarta: Penerbit PT Elex Media Komputindo

Saiful Mujani. (2020). Wabah Covid-19: Efektivitas Bantuan Sosial, Temuan Survey Nasional Update 5-6 Mei 2020. Working Paper. Jakarta: Saeful Mujani Research \& Consulting

SMERU. (2020). The Impact of Covid-19

Outbreak on Poverty: An Estimation for Indonesia. SMERU Working Paper, Jakarta: SMERU Research Institute

Wulandari, D., Utomo, S., Narmaditya, B. (2017). Waste Bank: Waste Management Model Improving Local Economy. International Journal Of Energy Economics and Policy, 7(30), 36-41
Yuwono, S., Partini. (2008). Influence of Entrepreneurship Training On The Growth of Entrepreneurship Interest. Jurnal Penelitian Humaniora, Vol 9 (2), 119-127 